\title{
Prediction of swell pressure in Neogene clays from Warsaw, based on the swell index
}

\author{
Ireneusz Gawriuczenkow, Emilia Wójcik \\ University of Warsaw, Faculty of Geology, Institute of Hydrogeology and Engineering Geology; \\ ul. Żwirki i Wigury 93, 02-089 Warsaw, Poland; \\ e-mail:i.gawriuczenkow@uw.edu.pl,wojcike@uw.edu.pl
}

(C) 2018 Authors. This is an open access publication, which can be used, distributed and reproduced in any medium according to the Creative Commons CC-BY 4.0 License requiring that the original work has been properly cited.

Received: 19 November 2017; accepted: 10 April 2018

\begin{abstract}
The paper presents the results of swell measurements of Neogene clays (Posnanian clay) from the Mazovia region with different grain size distribution and mineral composition. The study was conducted with model soil with initial moisture contents of $15 \%, 20 \%, 25 \%$ and $30 \%$. The basic physical properties of clays, their mineral composition and swelling parameters such as free swelling index and swelling pressure were determined. Free swell index was correlated to liquid limit, plasticity index, clay content and water content. A very high fit was found for a proposed relationship between the free swell index and swell pressure which offers an inexpensive method of predicting swell pressure in the preliminary stages of site investigation.
\end{abstract}

Keywords: Neogene clays, expansiveness, swell pressure, swell index

\section{INTRODUCTION}

Intense urban development results in increased demand for areas undeveloped to date due to unfavourable soil conditions. Presently, enhanced knowledge and technology allows for the accomplishment of objects even in complex soil conditions, nevertheless in each practical case the recognition of the foundation soil and the processes taking place within it is of crucial significance. Therefore, the range of analyses and the quality at which the geological structure is recognized should be adapted to its complication and to the soil conditions. In the case of expansive soils, which are particularly sensitive to environmental changes, shrinkage and swelling parameters, and water conditions should be determined.

Expansive soils occurringin many countries in the foundation pose serious challenges for engineers designing engineering objects. Particularly problematic are soils present in the vadose zone, whose volume may significantly decrease during dry seasons and which may swell during increased water content. Such problems have been extensively documented in Poland (Kumor 2016) and worldwide (Ruwaih 1987, Chen 1988, Nelson \& Miller 1992); moreover, the estimated costs related to the damage of infrastructure reach over a billion US dollars in the USA and over several billion US dollars around the world, justifying the need for specialized investigations.

Damage of engineering objects may be avoided or its effects may be minimized through the identification and precise determination of the values and ranges of parameters of expansive soils such as shrinkage, free swell, final water content and swell pressure. Beside shrinkage, swell pressure is a parameter that has a particular influence on the development of building damage located on soils with low saturation levels. Values of swell pressure exceeding $250 \mathrm{kPa}$ are considered critical in the assessment of the safety of construction objects (Alexander 1993). 
Correlation relationships between soil parameters are commonly sought (Yilmaz \& Yuksek 2009, Carte \& Bentley 2016) due to the fact that conducting laboratory tests and application of in situ techniques causes numerous technical problems, are costly and time consuming. Beside the number and representativeness of the collected samples, their quality is of large significance for the correctness of the parametric characteristics of the foundation soil (Wierzbicki \& Radaszawski 2016). Additionally, determination of some parameters of soil swelling may result in numerous problems related to the collection of samples displaying sufficient quality, completing relevant equipment for the investigations, long term analytic procedures, or a complex methodology. Therefore, indirect methods are commonly sought for the assessment of swell pressure. Additionally, the development of numerical models for the rapid assessment of this parameter based on cheap analyses such as free swell, supplemented with analysis of the influence of basic parameters, e.g. grain-size composition, mineral composition and water content, becomes a valuable source of data in the initial assessment of foundation soil.

To date there have been numerous investigations and analyses of factors influencing the swelling of cohesive soils (El-Sohby \& El-Sayed 1981). The compilation of the results presented in the existing, very extensive literature on the correlation of selected parameters of cohesive soils (i.e. water content, grain size composition, bulk density of the soil matrix, activity, liquid limit, plasticity index) with swell parameters is presented in Table 1. As indicated in this compilation, both soils with undisturbed structure, soils that were homogenized and compacted to expected densities, and soil mixtures composed of clay minerals (bentonite-kaolinite, etc.) were used in the analyses, which significantly influenced the obtained results.

\section{Table 1}

The empirical relationships for estimating swell index and swell pressure

\begin{tabular}{|c|c|}
\hline Relationship & Reference \\
\hline $\begin{array}{l}S_{p}=2.16 \cdot 10^{-3} \cdot P I^{2.44} \\
S_{p}=3.60 \cdot 10^{-5} \cdot(A)^{2.44} \cdot(C)^{3.44} \\
S_{p}=4.13 \cdot 10^{-4} \cdot(S I)^{2.67}\end{array}$ & Seed et al. $(1962)^{* * *}$ \\
\hline $\begin{array}{l}S_{p}=4.57 \cdot 10^{-5} \cdot[S I /(C-13)]^{2.67} \cdot(C)^{3.44} \\
S_{p}=4.113 \cdot 10^{-4} \cdot[S I /(C-13)]^{2.67} \cdot(C)^{3.44}\end{array}$ & $\begin{array}{l}\text { Ranganatham \& } \\
\text { Satyanarayan }(1965)^{* *}\end{array}$ \\
\hline $\log P_{s}=2.132+0.0208 \cdot L L+0.000665 \cdot \gamma_{\mathrm{dry}}-0.0269 \cdot w$ & Komornik \& David (1969)* \\
\hline $\begin{array}{l}P_{s}=3.5817 \cdot 10^{-2} \cdot P I^{1.12} \cdot\left(C^{2} / w^{2}\right)+3.7912 \\
P_{s}=2.29 \cdot 10^{-2} \cdot P I^{1.45} \cdot(C / w)+6.38\end{array}$ & $\begin{array}{l}\text { Nayak \& Christensen } \\
(1971)^{* *}\end{array}$ \\
\hline $\begin{array}{l}\log S=(1 / 12) \cdot(0.4 \cdot L L-w+5.5) \\
\log S=(1 / 19.5) \cdot\left(6.242 \cdot \gamma_{\text {dry }}+0.65 \cdot L L-130.5\right)\end{array}$ & $\begin{array}{l}\text { Vijayvergiya \& Ghazzally } \\
(1973)^{\star}\end{array}$ \\
\hline $\log S_{p}=0.0562 \cdot \gamma_{\text {dry }}+0.033 \cdot L L-6.8$ & $\begin{array}{l}\text { Vijayvergiya \& Sullivan } \\
(1973)^{\star}\end{array}$ \\
\hline $\log P_{s}=0.9 \cdot(P I / w)-1.19$ & Schneider \& Poor $(1974)^{*}$ \\
\hline
\end{tabular}




\begin{tabular}{|c|c|}
\hline $\begin{array}{c}S_{p}=7.5-0.8 \cdot w+0.203 \cdot C \\
\log P_{s}=-2.89-7 \cdot w+6.65 \cdot C\end{array}$ & $\begin{array}{l}\text { McCormack \& Wilding } \\
(1975)^{*}\end{array}$ \\
\hline$S_{p}=2.77+0.131 \cdot L L-0.27 \cdot w$ & O’Neil \& Ghazzally $(1977)^{*}$ \\
\hline $\begin{array}{l}\text { For } P I \geq 40 \text { : } \\
S_{p}=23.82+0.7346 \cdot P I-0.1458 \cdot H-1.7 \cdot w+0.0025 \cdot P I \cdot w-0.00884 \cdot P I \cdot H \\
\text { For } P I \leq 40: \\
S_{p}=-9.18+1.5546 \cdot P I+0.08424 \cdot H-0.1 \cdot w-0.0432 \cdot P I \cdot w-0.01215 \cdot P I \cdot H\end{array}$ & Johnson $(1978)^{*}$ \\
\hline$S_{p}=0.00001114 \cdot A_{c}^{2.559} \cdot C^{3.44}$ & Bandyopadhyay $(1981)^{*}$ \\
\hline$S_{p}=0.2558 \cdot e^{0.083 P I}$ & Chen $(1988)^{\star *}$ \\
\hline $\begin{array}{l}S_{p}=41.161 \cdot A_{c}+0.6236 \\
S_{p}=0.0763 \cdot \psi_{i}-339.03\end{array}$ & Cokca $(2002)^{\star * *}$ \\
\hline $\begin{array}{l}\log P_{s}=-4.812+0.01405 \cdot P I+2.394 \cdot \gamma_{\mathrm{dry}}-0.0163 \cdot w \\
\log P_{s}=-5.197+0.01405 \cdot P I+2.408 \cdot \gamma_{\mathrm{dry}}-0.819 \cdot w \\
\log P_{s}=-5.020+0.01383 \cdot P I+2.356 \cdot \gamma_{\mathrm{dry}}\end{array}$ & Erzin \& Erol $(2004)^{* * *}$ \\
\hline $\begin{array}{l}P_{s}=63.78 \cdot e^{0.1528 S} \\
P_{s}=48.32 \cdot S_{p}\end{array}$ & $\begin{array}{l}\text { Sridharan \& Gurtug } \\
(2004)^{* *}\end{array}$ \\
\hline $\begin{array}{l}S_{p}=1.00+0.006 \cdot(C+P I-w) \\
P_{s}=135.00+2 \cdot(C+P I-w)\end{array}$ & Sabtan $(2005)^{*}$ \\
\hline $\begin{array}{l}P_{s}=12.5 \cdot(0.001 \cdot \psi)^{0.25} \\
P_{s}=25 \cdot(0.001 \cdot \psi)^{0.25}\end{array}$ & Thakur \& Singh $(2005)^{\star * *}$ \\
\hline$P_{s}=-8.04+0.0177 \cdot P I+4.390 \cdot \gamma_{\mathrm{dry}}+0.540 \cdot \log \psi$ & Erzin \& Erol $(2007)^{\star * *}$ \\
\hline $\begin{array}{l}S_{p}=-432.06+7.73 \cdot C+0.12 \cdot C E C+0.46 \cdot P I+4.30 \cdot \gamma_{\mathrm{dry}}-1.18 \cdot w \\
P_{s}=-1346.2+257.10 \cdot C+43.13 \cdot C E C-18.18 \cdot P I+33.43 \cdot \gamma_{\mathrm{dry}}-25.21 \cdot w-3.41 \cdot S_{p} \\
P_{s}=1.9319 \cdot S_{p}^{1.2897}\end{array}$ & Erzin \& Gunes $(2011)^{\star * *}$ \\
\hline $\begin{array}{l}S_{p}=24.5 \cdot(P)^{-0.26}(P I \cdot C)^{1.26} \cdot\left[F_{i}-7.1 \cdot(P)^{0.22} \cdot(P I \cdot C)^{0.78}\right] \\
P_{s}=249 \cdot(P I \cdot C)^{1.18} \cdot\left[F_{i}-0.84 \cdot(P I \cdot C)^{-0.96}\right]\end{array}$ & Zumrawi (2012)** \\
\hline
\end{tabular}

* natural soils,

** compacted soils,

$* * *$ clay mixture.

Explanations: $S_{p}$ - swelling potential [\%], $P_{s}$ - swelling pressure [kPa], PI - plasticity index [\%], $L L$ - liquid limit [\%], $w$ - initial water content [\%], $\rho_{\text {dry }}$ - dry unit weight, $C$ - clay content [\%], $H$ - depth oh expansive layer [feet], CEC - cation exchange capacity $[\mathrm{meq} / 100 \mathrm{~g}], \psi-$ soil suction, $q$ - surcharge load $[\mathrm{kPa}], F_{i}$ - the initial state factor

This report attempts to determine the relationships between swell pressure and free swell of Neogene clays from the Warsaw area, finding the mathematical relationships in the form of an empirical formula allowing for the prediction of swell pressure based on analyses of physical parameters: 
liquid limit $L L$, natural water content $w_{n}$, plasticity index $P I$, grain size distribution, and analysis of archival formulas enabling the assessment of free swell and swell pressure in various soils worldwide.

\section{MATERIAL AND METHODS}

The analyses were conducted in Neogene clays (known as the 'Poznań series'), characterized as expansive soils (Kaczyński \& Grabowska-Olszewska 1997, Kumor 2008, 2016, Izdebska-Mucha \& Wójcik 2015) and collected from 6 sites in Warsaw. The series is developed as clay, rarely siltysandy sediments, formed in an extensive, shallow, inland water reservoir, whose range covered almost the entire Polish Lowlands until the margin of the Sudetes. The series comprises three lithostratigraphic units that developed from the Middle Miocene to the Lower Pliocene (Piwocki 2002). Particular horizons differ in the sedimentary setting, geochemical conditions, variable mineral composition of the clay fraction, and macroscopically in colour.

The basic physical and physical-chemical parameters were analysed in each sample, e.g. grain size composition, bulk density, density of the soil skeleton (using the AccuPyc 1330 gas pycnometer), soil consistency (plasticity limit PL and liquid limit $L L$ ), and soil specific surface using the methylene blue sorption method. The analyses were in accordance with PN-88/B-04481 and the liquid limit was determined using the Casagrande method (Tab. 2).

Table 2

Properties of the soils used in this study.

\begin{tabular}{|l|c|c|c|c|c|c|}
\hline \multicolumn{1}{|c|}{ Parameter } & Soil A & Soil B & Soil C & Soil D & Soil E & Soil F \\
\hline Particle density $\rho_{s}\left[\mathrm{Mg} / \mathrm{m}^{3}\right]$ & 2.71 & 2.70 & 2.70 & 2.70 & 2.78 & 2.75 \\
\hline Bulk density $\rho\left[\mathrm{Mg} / \mathrm{m}^{3}\right]$ & 1.71 & 1.66 & 1.52 & 1.78 & 1.73 & 1.71 \\
\hline Porosity $n[\%]$ & 36.9 & 38.5 & 43.7 & 34.1 & 37.8 & 37.8 \\
\hline Degree of saturation $S_{r}[-]$ & 0.86 & 0.94 & 0.92 & 0.99 & 0.99 & 0.83 \\
\hline Activity $A[-]$ & 0.74 & 0.82 & 0.68 & 0.81 & 0.81 & 0.77 \\
\hline Clay content $C[\%]$ & 36.6 & 38.8 & 53.7 & 57.1 & 60.7 & 63.9 \\
\hline Clay mineral content $[\%]$ & 40.1 & 38.9 & 46.9 & 56.9 & 64.2 & 67.2 \\
\hline Ca-beidellite content $[\%]$ & 32.2 & 30.2 & 39.9 & 44.1 & 51.0 & 56.5 \\
\hline Liquid limit $L L[\%]$ & 46.2 & 51.5 & 57.6 & 70.6 & 74.7 & 82.2 \\
\hline Plasticity index $P I[\%]$ & 27.0 & 32.0 & 36.6 & 46.2 & 49.0 & 49.1 \\
\hline Specific surface area $\left[\mathrm{m}^{2} / \mathrm{g}\right]$ & 124.17 & 120.89 & 158.52 & 224.06 & 231.39 & 251.28 \\
\hline Colour & yellow- & yellow- & grey & grey & yellow & yellow \\
\hline
\end{tabular}

Mineralogical identification of particular components of the clay was tested by determining the mineral composition using thermal analysis in TA Instruments Q600. The thermal analysis was conducted in an oxygen atmosphere, at a heating rate of $10^{\circ} \mathrm{C} / \mathrm{min}$, with the resolution of particular curves automatically selected by the apparatus. Precise determination of the mineral composition (particularly of clay minerals) was made in two ways: for a natural sample of the clay and for the fraction below $2 \mathrm{~mm}$ obtained in the sedimentation method. Identification of clay minerals and assessment of the percentage contribution was based on the knowledge of the values of dehydratation $(d h)$, dehydroxylation $(d h o)$, and the temperature range, in which these processes took place (Kościówko \& Wyrwicki 1996).

There is a large variety of swelling tests depending on the aim of the analysis and the available equipment. In the literature (Sridharan et al. 1985, Kaczyński \& Grabowska-Olszewska 1997) there are various methodological and interpretation concepts for determining the swell index (e.g. test without loading of sample or at a specific load, free swell test) and the swell pressure (e.g. method of gradual load of a swelled sample according to 
ASTM D4546-14, method of a series of samples according to $\mathrm{PN}-88 / \mathrm{B}-04481$ ).

During the presented investigations, analyses of uniaxial free swell were conducted according to ASTM D 4546-14 (method A) in a swell meter. Swell pressure was measured in a Geonor H-200A apparatus at a stable sample volume maintained by the device by imposing vertical pressure on a saturated sample, which does not allow the sample to swell and thus to increase its volume (ASTM D 4546-14 - method C).

In the case of swell index, samples 8 to $12 \mathrm{~mm}$ in height and $65 \mathrm{~mm}$ in diameter were cut out. Next, they were inserted in a ring and in a swell meter, detectors were set and containers were filled with deionised water, so that sample saturation took place from the bottom. Samples were subject to vertical stress of $1.5 \mathrm{kPa}$ imposed through the copula covering the samples. Observations of swell (increase of sample height) were conducted until the end of soil swelling, determined by lack of changed values on the detector during three subsequent readings. Analyses of the swell index were conducted for six natural soils, and additionally, to determine the influence of water content change on its values, model samples were prepared from each clay characterized by assumed initial water content $w_{0}$ at $15 \%, 20 \%, 25 \%$ and $30 \%$, densified in a Proctor apparatus to a maximal bulk density that was possible to attain. The free swell index was determined according to formula (1):

$S_{p}=\frac{h-h_{0}}{h_{0}} \cdot 100 \%$

where:

$S_{p}$ - free swell index [\%],

$h$ - sample height after swelling [mm],

$h_{0}$ - initial sample height [mm].

After swelling, final soil parameters were determined, such as final water content $w_{f}$, bulk density and saturation index.

Analyses of swell pressure were conducted on model samples with initial water content $w_{0}$ at $15 \%$, $20 \%, 25 \%, 30 \%$, and bulk density $\rho$ accordingly $2.23 ; 2.08 ; 2.03 ; 1.98 \mathrm{Mg} / \mathrm{m}^{3}$ prepared identically as for the swell index analyses. The cut-out samples with a diameter of about $50 \mathrm{~mm}$ and height of $1.98 \mathrm{~mm}$ were inserted in a ring, and next in a Geonor apparatus in a special container. The samples were initially loaded with a pressure of $8.5 \mathrm{kPa}$ and the height detector, steering an engine neutralizing all changes of sample height with a resolution of $0.01 \mathrm{~mm}$, was set. The sample was covered with deionised water so that saturation took place from the bottom. After achieving the relative stabilization of the swell pressure values, i.e. lack of increased values in three subsequent readings, the test ended, and similarly as in the case of free swell, final soil parameters were determined.

\section{TEST RESULTS}

The conducted tests indicate that Neogene clays are characterized by a variable contribution of the clay fraction from $36 \%$ to $64 \%$, which classifies them as very cohesive soils, and a significantly high contribution of clay minerals from $38 \%$ to $67 \%$, with the dominant Ca-beidellite at $30-57 \%$ (Tab. 2). As assumed, these parameters influence many geological-engineering properties of soils, such as: values of consistency limits, particularly the liquid limit LL, shrinkage, swell, swell pressure, etc. Figure 1 presents the relationships between liquid limit LL values for the analysed clays and the contribution of the clay fraction (Fig. 1A), content of the clay minerals (Fig. 1B), content of beidellite (Fig. 1C) and specific surface (Fig. 1D). Because these relationships indicate a very strong linear correlation R2 from 0.90 to 0.96 , it may be assumed that the liquid limit reflects the influence of the analysed parameters on its values. By using the liquid limit LL to predict soil swelling $S p$, the amount of analyses may be minimized. This concept is confirmed by the high correlation between $L L$ and clay swelling (Fig. 2). Analysis of the influence of water content on swelling has indicated a trend according to which correlation slightly increases with water content decrease, as well as the inclination of particular trend lines becomes larger, which suggests the larger influence of initial water content on swelling compared to other variables.

Currently, regression analysis is increasingly being applied to assess soil properties in engineering geology (Sulewska 2010, Erzin \& Gunes 2013, Carte \& Bentley 2016). Multifactor regression analysis (MRA) with the application of STATISTICA 12 software was used to obtain the correlation formula of the swell index for Neogene clays from Warsaw 
depending on clay properties, such as the clay fraction content $C$, content of clay minerals $m_{i}$, plasticity index $P I$, liquid limit $L L$, water content $w_{n}$, and specific surface $S S A$. Based on the regression analysis and using parameters such as water content, clay fraction content, plasticity index, and liquid limit, it was possible to determine the formulas and select those characterized by the highest linear coefficient of determination:

$S_{p}=25.202+0.643 \cdot L L-2.089 \cdot w_{n} \quad R^{2}=0.91$

$S_{p}=29.692+0.914 \cdot P I-2.089 \cdot w_{n} \quad R^{2}=0.89$

$S_{p}=29.974-\left(2.089 \cdot w_{n}\right)+\left(0.700 \cdot f_{i}\right) \quad R^{2}=0.84(4)$
Analysis of these formulas shows that the highest coefficient of determination $R^{2}$ is achieved by formula (2), which confirms the high dependence between measured values of the swell index, and natural water content (or initial water content) and liquid limit. Using STATISTICA12 software, a test was conducted to compare differences between predicted and measured values of the swell index. The obtained correlation values at 0.96 (Fig. 3) indicate that the proposed formula (2) is precise enough, and the parameters of physical properties such as natural (initial) water content and liquid limit may be used (give correct results) for a preliminary assessment of the swelling of Neogene clays from Warsaw.

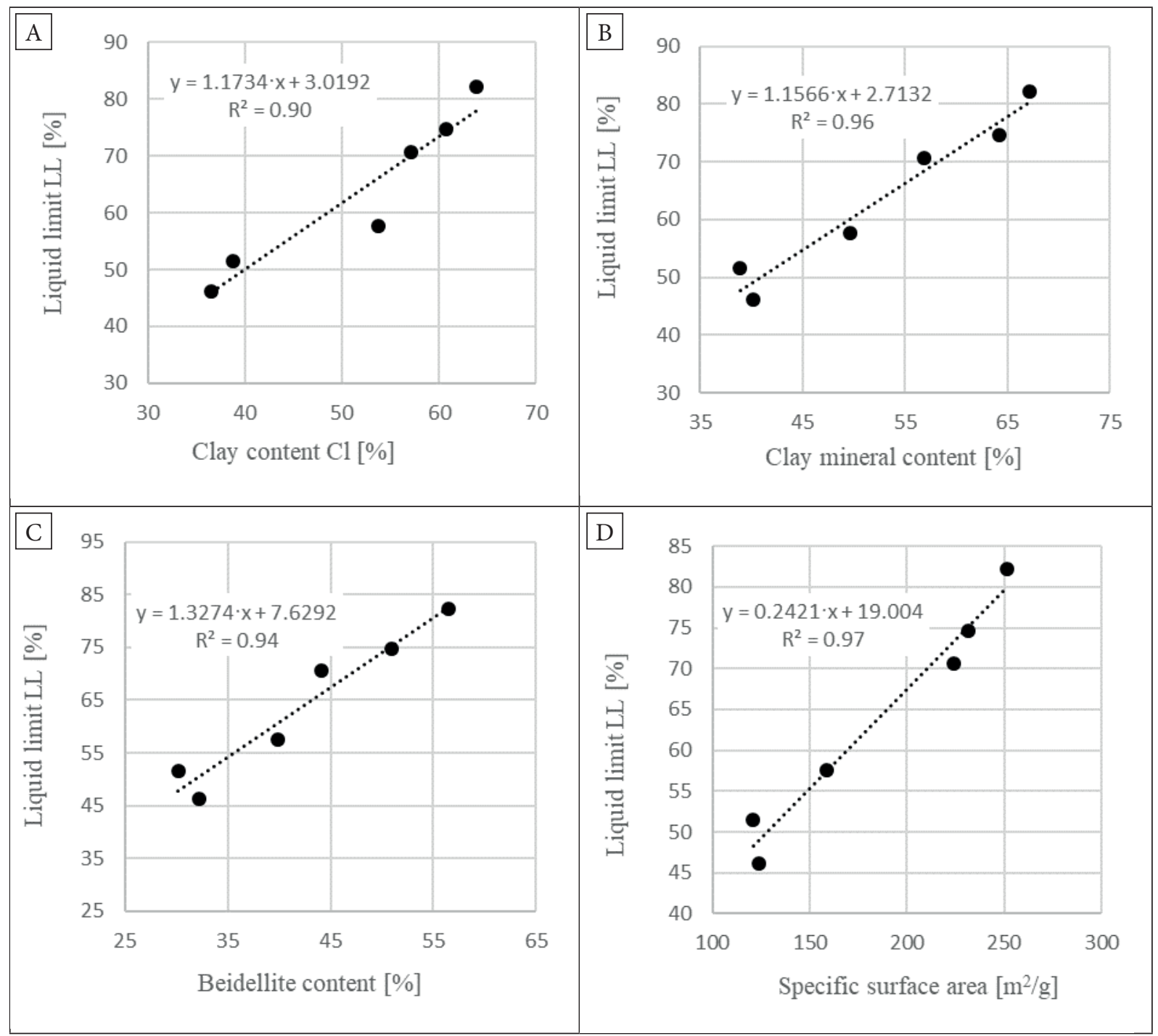

Fig. 1. The relationship between liquid limit and clay content (A), mineral content (B), beidellit content (C), specific surface area (D) 


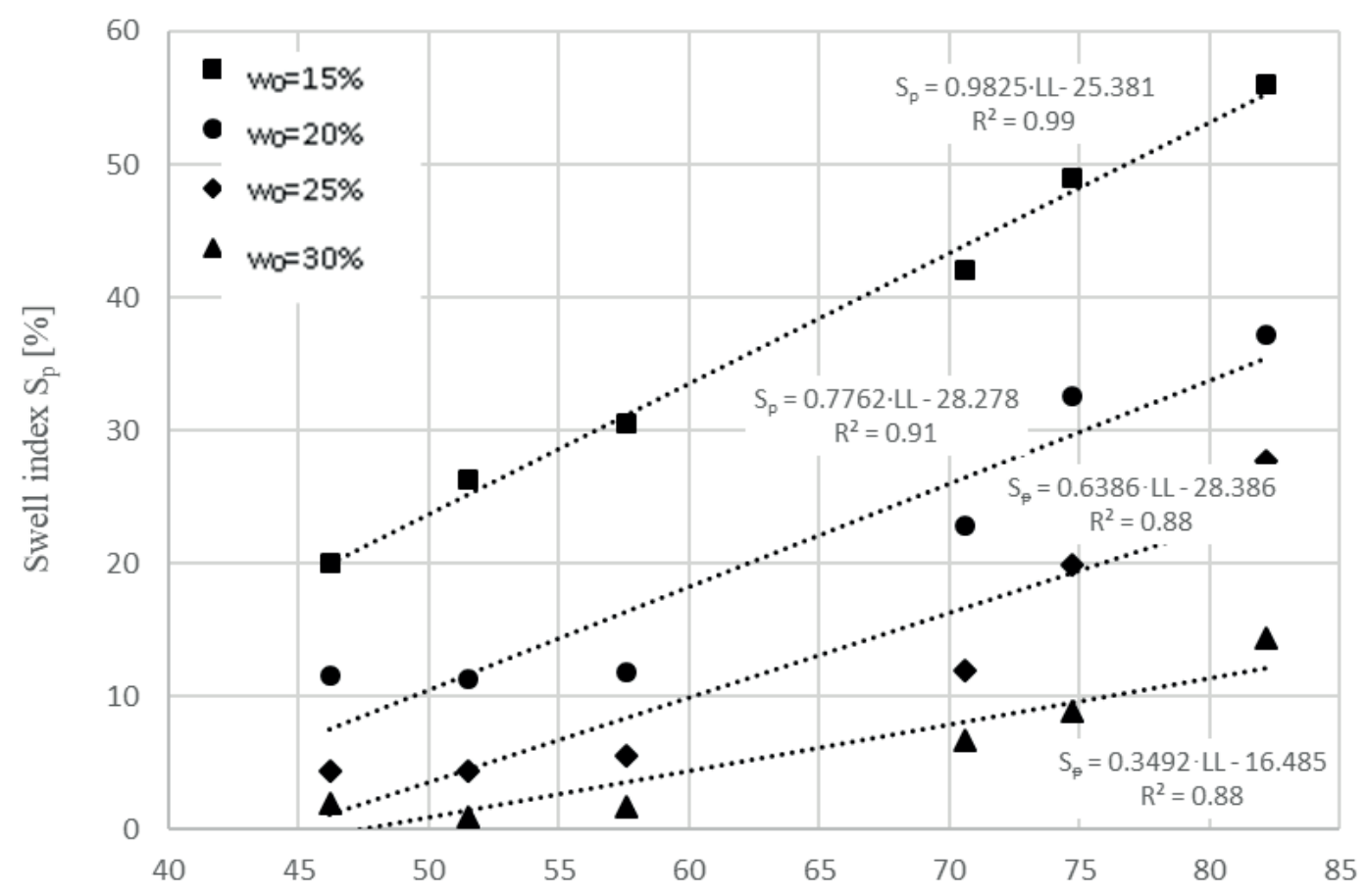

Liquid limit LL [\%]

Fig. 2. The relationship between liquid limit and swell index for modified clay with different moisture content

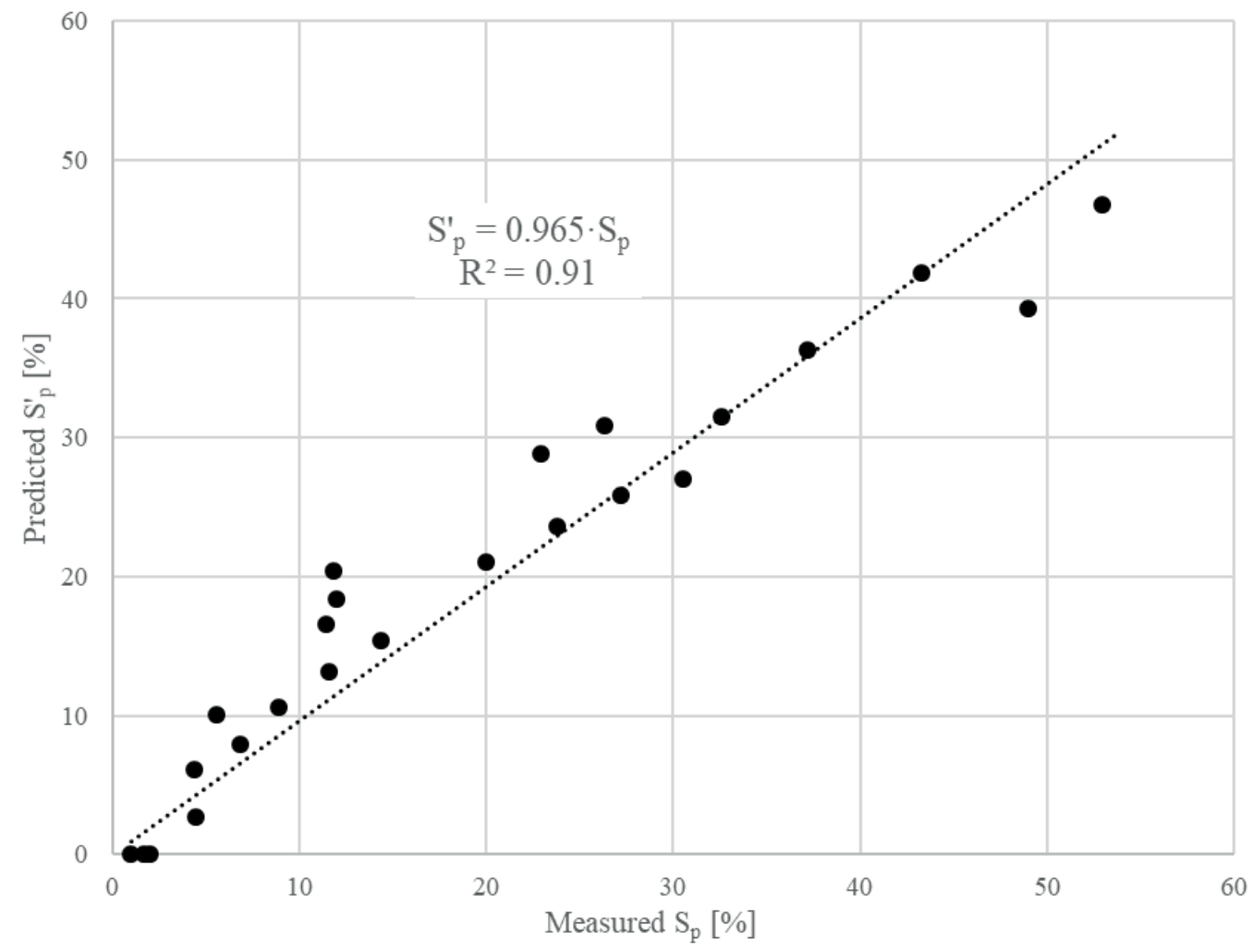

Fig. 3. The relationship between measured and predicted swell index 
A much more complex analysis, both with regard to methodology and interpretation, is the analysis of swell pressure, particularly when using norm PN-88/B-04481. Thus, a question arises: can analyses of the swell index be used to predict the values of swell pressure? The conducted analyses give an ambiguous answer. In the lower ranges of swell pressure, as indicated in Figure 4, there is high linear relationship between swell pressure and swell index (formula (5)). In turn, at swell pressure values exceeding $400 \mathrm{kPa}$, the correlation between these parameters may be lower or have a non-linear character:

$\mathrm{s}_{s p}=8.8553 \cdot S_{p}$ where $R^{2}=0.90$

Similar conclusions, based on their own analyses, have been drawn by Erzin \& Gunes (2013), where a strong correlation at $R=0.89$ between values of free swell and swell pressure was observed for swell pressure values below $300 \mathrm{kPa}$. At higher values of swell pressure, these relationships were much lower.

Therefore, based on the predicted swell index and the measured swell index, values of swell pressure were calculated from formula (5) and compared to values obtained from analyses in the Geonor apparatus; the result is presented in Figure 5. In this case there is also a strong correlation at $R^{2}=0.85$ (a) and $R^{2}=0.92$ (b) with the swell pressure obtained in analyses and swell pressure predicted on the basis of the calculated swell index (a) from formula (2) and swell index measured in the swell meter (b).

Application or extension of this formula onto other clay sediments (of the same age but occurring in other areas) will be possible after further investigations because the analysis of empirical formulas (Tab. 1) proposed by other scientists (for other soils) indicates a significant discrepancy in the obtained results (Fig. 6).

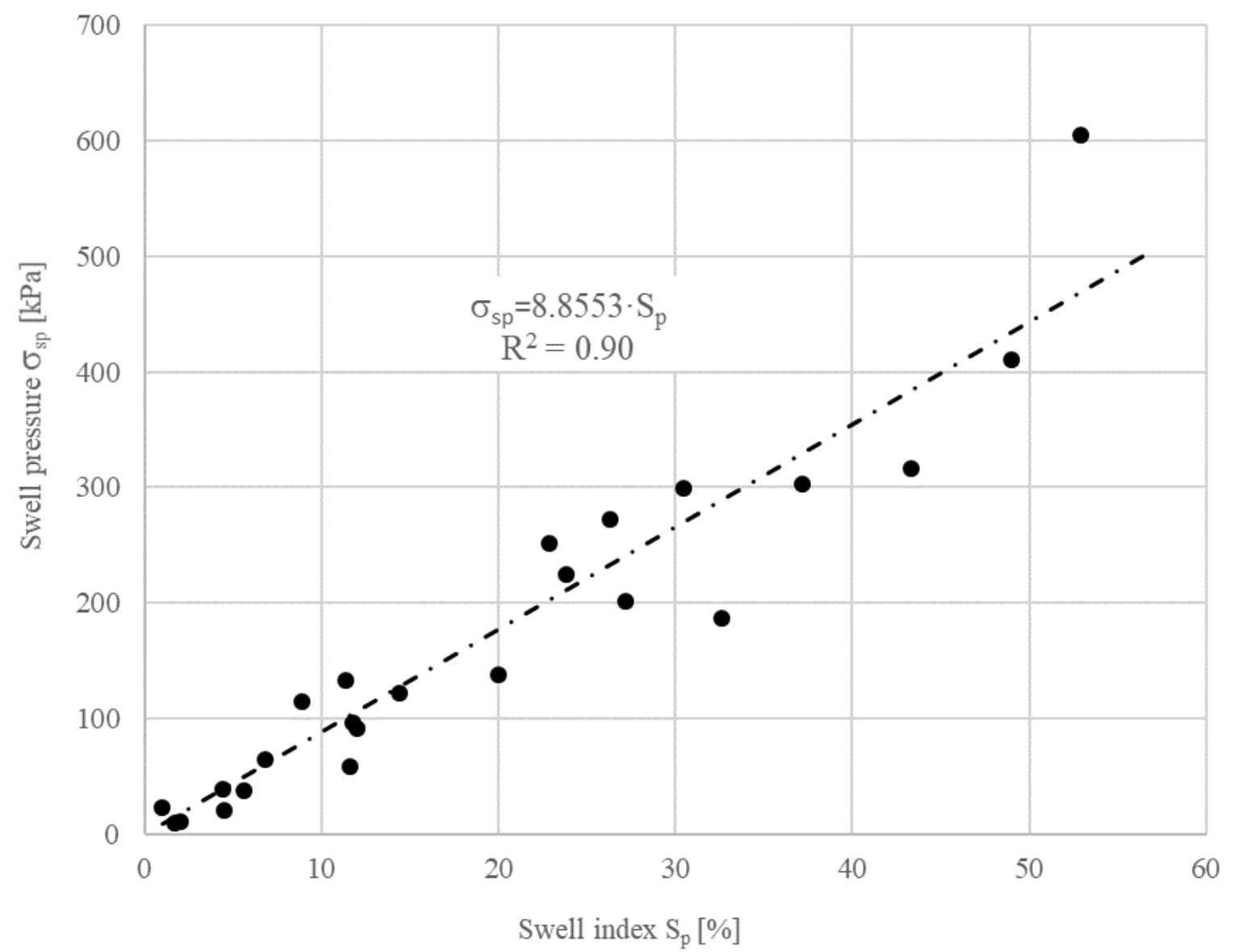

Fig. 4. The relationship between swell index and swell pressure 


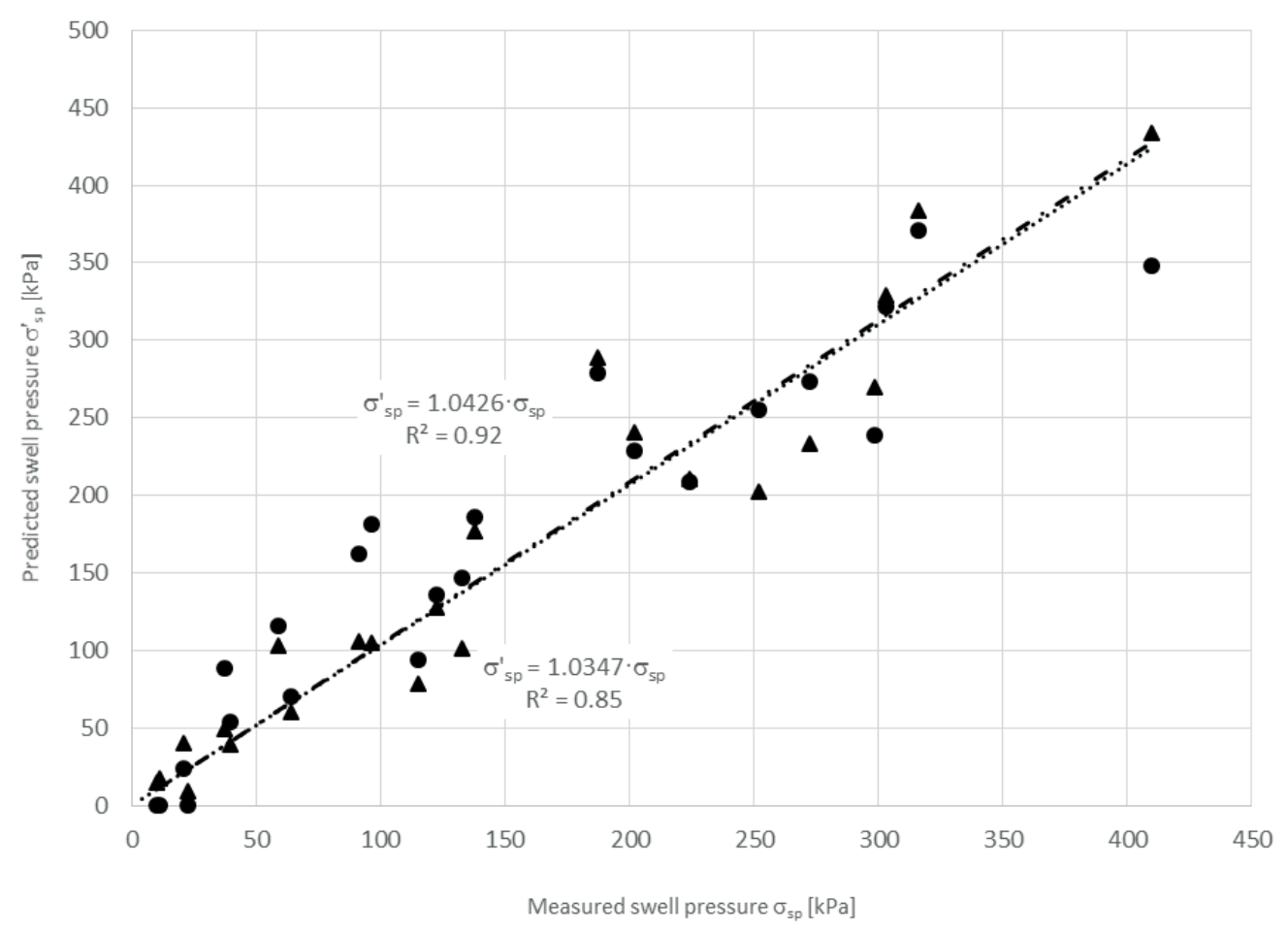

Fig. 5. The relationship between measured and predicted swell pressure

Therefore, predicted values of swell pressure values of swell pressure from empirical formulas should be treated as preliminary. Obtaining high should impel laboratory analyses of this parameter.

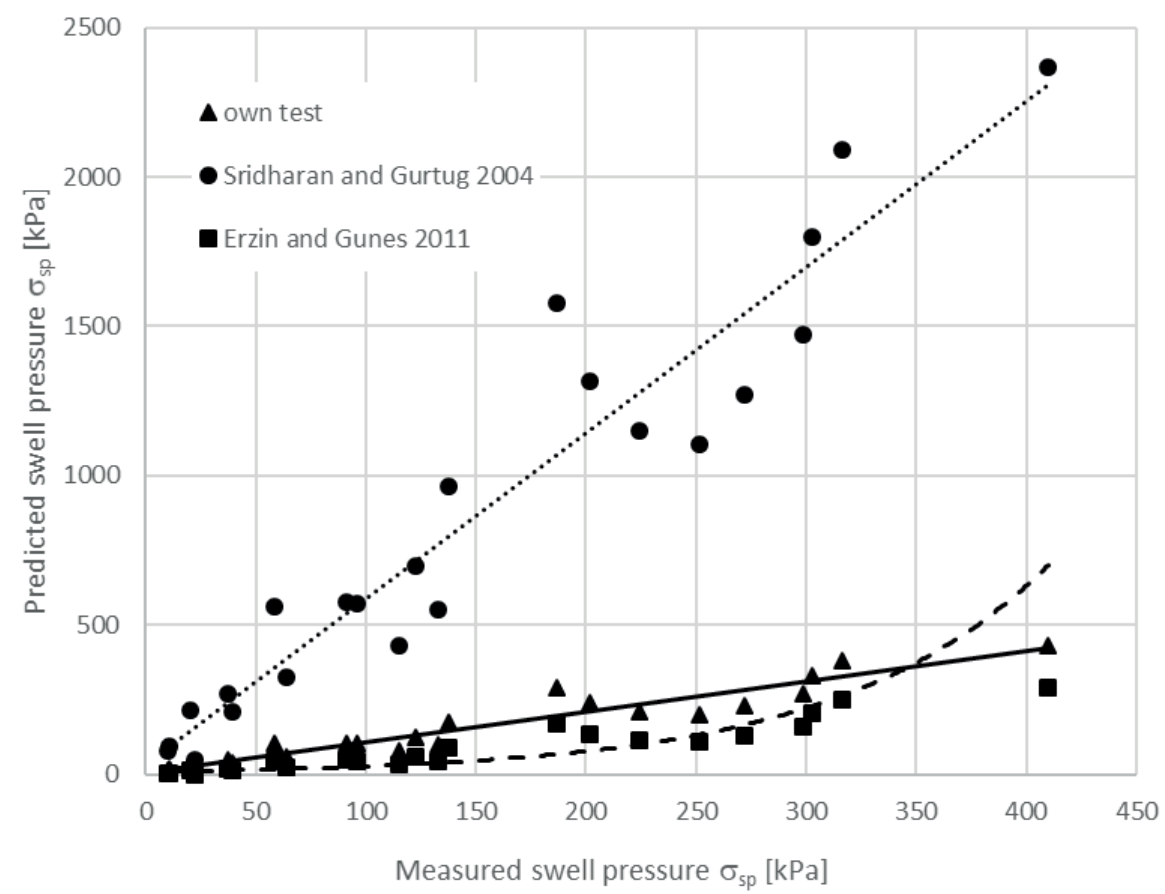

Fig. 6. The relationship between measured swell pressure Neogene clays and predicted swell pressure based on formulas: own, Sridharan \& Gurtug (2004) and Erzin \& Gunes (2011) 


\section{CONCLUSIONS}

Based on the analysis of the physical parameters of Neogene clays from the Warsaw area, it has been established that liquid limit perfectly reflects the influence of clay fraction content, mineral composition and beidellite content on its values, i.e. parameters that beside water content have significant influence on the swell properties of soils. Analyses on model samples (with assumed water content) have confirmed the influence of water content on clay swelling. Application of regression analyses has allowed for the determination of the relationship of the free swell index in relation to liquid limit and initial water content, and for deriving a simple formula for the fast assessment of the swell index based on these parameters. A strong relationship at $R^{2}=0.91$ was determined between swell index obtained in laboratory tests and the swell index calculated from formula (2), which allows for applying formula (2) in the calculation of this parameter.

Analyses of swell index and swell pressure have allowed for the determination of a linear relationship (formula (5)) between these parameters, but only for swell pressure values below $400 \mathrm{kPa}$. Above these values, the relationship between these parameters is weaker, which indicates a greater influence of water content on the value of swell pressure than on the free swell index. Moreover, the application of empirical formula (5) for the assessment of swell pressure based on the swell index is possible only for clays from the analysed area, as indicated by the analysis of soil tests from other parts of the world.

\section{REFERENCES}

ASTM D2487-11. Standard practice for classification of soils for engineering purposes.

ASTM D 4546-14. Standard test Method for one-dimensional swell or collapse of soils.

Alexander D.E., 1993. Natural Disasters. Kluwer Academic Publisher, Dordrecht.

Bandyopadhyay S.S., 1981. Prediction of swelling potential for natural soils. Journal of Geotechnical Engineering Division, 107, 5, 658-691.

Brackley I.J., 1975. Swell under load. [in:] Pells P.J.N. \& Robertson A.MacG. (eds.), Soil Mechanics and Foundation Engineering: Proceedings of the Sixth Regional Conference for Africa, Durban, 1975, A.A. Balkema, Cape Town, 65-70.

Carter M. \& Bentley S.P., 2016. Shrinkage and Swelling Characteristics, in Soil Properties and their Correlations. John Wiley \& Sons, Chichester, UK. DOI: 10.1002/9781119130888.ch8.
Chen F.H., 1988. Foundation on Expansive Soils. Elsevier, Amsterdam.

Cokca E., 2002. Relationship between methylene blue value, initial soil suction and sweel percent of expansive soils. Turkish Journal of Engineering and Environmental Science, 26, 521-529.

El-Sohby M.A. \& El-Sayed A.R., 1981. Some factors affecting swelling of clayey soils. Geotechnical Engineering, 12, 19-39.

Erzin Y. \& Erol O., 2004. Correlations for quick prediction of swell pressures. The Electronic Journal of Geotechnical Engineering, 9(F), 0476.

Erzin Y. \& Erol O., 2007. Sweeling pressure prediction by suction method. Engineering Geology, 92, 133-145.

Erzin Y. \& Gunes N., 2011. The prediction of swell percent and swell pressure by using neural networks. Mathematical and Computational Applications, 16, 2, 425-436.

Erzin Y. \& Gunes N., 2013. The unique relationship between swell percent and swell pressure of compacted clays. Bulletin of Engineering Geology and the Environment, 72,71-80.

Izdebska-Mucha D. \& Wójcik E., 2015. Evaluation of expansivity of Neogene clays and glacial tills from central Poland on the basis of suction tests. Geological Quarterly, 59, 3, 593-602.

Johnson L.P., 1978. Predicting potential heave and heave with time in swelling foundation soils. US Army Engineer Waterways Experiment Station, CE, Vicksburg, Miss. Technical report S-78-7.

Johnson L.P. \& Snethen D.R., 1978. Prediction of potential heave of swelling soil. Geotechnical Testing Journal, 1, 3, $117-124$.

Kaczyński R. \& Grabowska-Olszewska B., 1997. Soil mechanics of the potentially expansive clays in Poland. Applied Clay Science, 11, 337-355.

Komornik A. \& David D., 1969. Prediction of swelling pressure of clays. Soil Mechanics and Foundation Engineering, 95, 1, 209-225.

Kościówko H. \& Wyrwicki R., 1996. Metodyka badań kopalin ilastych. Państwowy Instytut Geologiczny, Warszawa.

Kumor M.K., 2008. Selected Geotechnical Problems of Expansive Clays in the Area of Poland. Architecture Civil Engineering Environment, 4, 75-92.

Kumor M.K., 2016. Iły ekspansywne podłoża budowlanego Bydgoszczy: wybrane problemy geotechniczne. Wydawnictwa Uczelniane Uniwersytetu Technologiczno-Przyrodniczego, Bydgoszcz.

McCormack D.E. \& Wilding L.P., 1975. Soil properties influencing swelling in Canfield and Geeburg soils. Soil Science Society of America Journal, 39, 3, 496-502.

Nayak N.V., 1979. Foundation Design Manual. Dhanpat Rai and Sons, Delhi.

Nayak N.V. \& Christensen R.W., 1971. Swelling characteristics of compacted expansive soil. Clays and Clay Minerals, 19, 251-261.

Nelson J.D. \& Miller D.J., 1992. Expansive soils: problems and practice in foundations and pavement engineering. John Wiley, New York.

O’Neil M.W. \& Ghazzally O.I., 1977. Swell potential related to building performance. International Journal of Geotechnical Engineering, 103, 12, 1363-1379.

Piwocki M., 2002. Ewolucja poglądów na stratygrafię utworów formacji poznańskiej na Niżu Polskim. Przegląd Geologiczny, 50, 3, 255. 
PN-88/B-04481. Grunty budowlane - Badania próbek gruntu. Polski Komitet Normalizacyjny, Warszawa.

Ranganatham B.V. \& Satyanarayan B., 1965. A rational method of predicting swelling potential for compacted expansive clays. [in]: Proceedings of the $6^{\text {th }}$ International Conference on Soil Mechanics and Foundation Engineering. Vol. 1, International Society for Soil Mechanics and Foundation Engineering, London, 92-96.

Ruwaih I.A., 1987. Experiences with expansive soils in Saudi Arabia. [in]: Proceedings: 6th International Conference on Expansive Soils, 1-4 December 1987, New Delhi, India. Lectures, additional papers, general reports, The Board, 317-322.

Sabtan A.A., 2005. Geotechnical properties of expansive clay in Tabuk, Saudi Arabia. Journal of Asian Earth Sciences, $25,747-757$.

Schneider G.L. \& Poor A.R., 1974. The prediction of soil heave and swell pressures developed by expansive clay. Research Report, N TR-9-74. Construction Research Center, University of Texas.

Seed H.B., Woodward R.J. \& Lundgren R., 1962. Prediction of swelling potential for compacted clays. Proceedings of the American Society of Civil Engineers Journal of the Soil Mechanics and Foundations Division, 88, SM3, 53-87.

Sridharan A. \& Gurtug Y., 2004. Swelling behavior of compacted fine grained soils. Engineering Geology, 72, 9-18.

Sridharan A., Rao S.M. \& Murthy N.S., 1985. Free Swell Index of Soils: A Need for Redefinition. Indian Geotechnical Journal, 15, 2, 94-99.
Sulewska M.J., 2010. Prediction models for minimum and maximum dry density of non-cohesive soils. Polish Journal of Environmental Studies, 19, 4, 797-804.

Thakur V.K.S. \& Singh D.N., 2005. Rapid determination of swelling pressure of clay minerals. Journal of Testing and Evaluation, 33, 4, 1-7.

Vijayvergiya V.N. \& Ghazzally O.I., 1973. Prediction of swelling potential of natural clays. [in:] Proceedings of the Third International Conference on Expansive Soils: Haifa, July 30-August 1, 1973. Vol. 1, Academic Press, 227-234.

Vijayvergiya V.N. \& Sulvian R.A., 1973. Simple technique for identifying heave potential. [in:] Proceedings of Workshop on Expansive Clays and Shales in Highway Design and Construction, December 13-15, 1972. Vol. 1, University of Wyoming, Laramie,149-154.

Wierzbicki J. \& Radaszewski R., 2016. O specyfice parametru gruntowego w badaniach geologiczno-inżynierskich. Przegląd Geologiczny, 64, 9, 694-700.

Williams A.A.B. \& Donaldson G.W., 1980. Buildings on expansive soil in South Africa: 1973-1980. [in:] Proceedings of the Fourth International Conference on Expansive Soils: Stouffer's Inn, Denver, Colorado, June 16-18, 1980. Vol. 2, ASCE, New York, 834-844.

Yilmaz I. \& Yuksek G., 2009. Prediction of shear strength and elasticity modulus of gypsum using multiple regression, ANN, and ANFIS models. International Journal of Rock Mechanics and Mining Sciences, 46, 803-810.

Zumrawi M.M.E., 2012. Prediction of swelling characteristics of expansive soils. Sudan Engineering Society Journal, 58, 2, 55-62. 